\title{
Self-Evaluation as a Factor of Quality Assurance in Education
}

\author{
Vesna Podgornik $^{1} \&$ Jasna Mažgon ${ }^{1}$ \\ ${ }^{1}$ Faculty of Arts, University of Ljubljana, Ljubljana, Slovenia \\ Correspondence: Jasna Mažgon, Department of Educational Sciences, Faculty of Arts, University of Ljubljana, \\ Aškerčeva 2, SI-1000 Ljubljana, Slovenia. Tel: 386-41-634-285. E-mail: jasna.mazgon@ff.uni-lj.si
}

Received: January 22, 2015 Accepted: February 9, 2015 Online Published: May 14, 2015

doi:10.5539/res.v7n7p407 URL: http://dx.doi.org/10.5539/res.v7n7p407

\begin{abstract}
Using an empirical research study based on a systematic sample of teachers, school counselors, and principals working in Slovenian primary and secondary schools, we examined how frequently these education professionals self-evaluate their work. The multiple regression models demonstrated that educators' interest in research work and belief in the necessity of continuous professional development have the strongest impact on their views of the importance of self-evaluation. Those educators whose knowledge of conducting self-evaluation is greater also attach more importance to carrying out self-evaluation. School management's encouragement has a further impact on educators' views on the importance of conducting self-evaluation. If an educational institution is to adopt self-evaluation as a permanent expert activity, which is a precondition for effective quality improvement, it needs to develop an adequate atmosphere among its educators. This atmosphere should enable and encourage research work, self-evaluation, and educators' professional development.
\end{abstract}

Keywords: self-evaluation, professional development, quality assurance, quality control, total quality management

\section{Introduction}

The processes of assessing and assuring quality are closely related to research work, more specifically to carrying out self-evaluation research studies. When responsibility for quality assurance is allocated to an individual school, it is assumed that educators are motivated, as well as qualified, to carry out self-evaluation. The idea that educators should undertake research work originates in the English project Ford Teaching Project (1973-1976), which trained educators to self-evaluate educational practice and to conduct action research studies (Stenhouse, 1975). Self-evaluating educational practice was perceived as belonging to the educator's everyday tasks, and the results of self-evaluation were utilized as the basis for further planning of educational work.

Evaluation is a process of establishing to what degree, and in what manner, we have reached our goals. Through evaluation, we collect evidence and reach provable findings on the quality of programs, projects, services, organizations, and individuals' work (Stufflebeam \& Shinkfield, 2007). This requires the systematic use of social science research methods to assess the plans, implementation, outcomes, and efficiency of programs, policies, or units of analysis (Rossi \& Freeman, 1993, p. 4). Evaluation falls within the realm ofapplied social science research. As a form of applied research evaluation differs from basic research, which is directed toward further theory development, in that it is focused on changing existing conditions, its fundamental aim is practical progress. Interim and final conclusions form the basis for the development of the plans for further work, and these plans include the introduction of changes and improvements directly related to pedagogical practice. Self-evaluation can also be defined as a reflection on the important aspects of educational work and leading to the assessment of the current work done by an educational institution, or as a planned, systematic, structured, and constant attention that schools pay to the quality of their work. Data collected through self-evaluation and their interpretation, as well as the analysis of the causes of the existing situation, are the foundations used to plan how to eliminate weaknesses and to maintain positive achievements. Thus, they are of key importance for institutional and individual quality improvement and maintenance.

Quality in education should be understood in the context of the relevant cultural discourse (Stronach, 1999; Gaber \& Kos Kecojevič, 2011). According to Sallis (2002), quality is a dynamic concept that is impossible to define in absolute terms, as it can have a variety of meanings. When defining quality, it is always necessary to have a debate about what it is that makes a school "good". Sallis (2002, pp. 3-4) defines four quality imperatives: 
(1) the moral imperative, which stipulates that all the "clients" (students, parents and the community) deserve the highest possible quality of education service; (2) the professional imperative, closely linked to the moral imperative, which suggests that everybody in the institution has a duty to provide students with the educational process that meets the highest possible standards; (3) the competitive imperative, which charges educational institutions with the task of meeting the challenge of competition, with one of the most effective ways being constantly improving one's services and processes; and (4) the accountability imperative, which defines educational institutions as part of their communities and, as such, they are expected to act responsibly toward their founders, including the public demonstration of their high standards and services.

Describing the process of quality assessment and assurance, various authors (Sallis, 2002; Dahlgaard, Kristensen, \& Kanji, 2002) describe three fundamental approaches to quality: (1) quality control; (2) quality assurance; and (3) total quality management (Note 1). Quality control includes the planned and systematic supervision over the processes and outcomes, as well as the introduction of necessary activity adjustments, with the aim of achieving specified requirements. Quality control is usually carried out by responsible authorities, that is, inspectorates, who control conditions for factors such as the start of work, the course of work, relevant documentation, and employees' qualifications. Quality assurance differs from quality control in that quality control aims at finding and correcting faults, while the main task of quality assurance is preventing faults, or their recurrence. This approach is internally accepted and adopted by all the employees who follow the path of quality improvement. Standards and criteria are established within the organization. Quality assurance is thus part of the functioning of an institution, while ensuring such conditions of functioning that will allow for the attainment of predetermined goals (cf. Sallis, 2002; Dahlgaard et al., 2002).

Total quality management is a conceptual approach that focuses on internal and omnipresent quality improvement. It emphasizes the participation of all employees-always, in all processes. This approach originated in postwar Japan's economy, as a lever for improving productivity. The idea was that such quality management approach would also affect the quality of life. In the 1980s, the approach spread to other fields, including education. Its philosophy is continuous improvement with an emphasis on the customer's needs and adopting the principles of the so-called "Deming circle" or "quality circle" (Powell, 1995). The quality circle is a method consisting of four stages: (1) plan; (2) do; (3) check; and (4) act. Cyclically moving from one stage to another, we advance spirally, returning to the same stages but at other, new levels. Quality assessment and assurance become significant only when they are made a part of everyday activities in the educational institution and provide constant feedback about the effects and efficiency of work.

Focusing quality assessment and assurance on self-evaluation, Slovenia has decided to move away from emphasizing quality assessment and assurance as processes of control over the work of educational institutions and educators. Rather than stressing the external verification of achievements and the planning procedures intended for their improvement, we are now transferring care for educational quality to institutions and to educators themselves.

\section{Defining the Purpose and Methodology of the Research Study}

\subsection{The Goals and Purposes of the Research Study}

In recent decades, numerous countries have directed their attention toward the notion of quality in education. Recent projects have started with the assumption that, if we propose that self-evaluation results should be a basis for the further planning of educational work, the notion of quality must be developed at the level of the professional autonomy of each school and the individual educator. The frequency of carrying out self-evaluation research, however, does not depend only on the expertise of conducting self-evaluation research but also on the views or beliefs that educators have about the importance of conducting such research. Therefore, the empirical part of our study focused on the analysis of principals', teachers' and school counselors' views on the importance of carrying out self-evaluation research for a good-quality educational process.

We examined

- Whether there are differences among principals, teachers, and counselors in primary and secondary schools with regard to how often, and in what areas, they carry out self-evaluation;

- Whether there are differences among primary- and secondary-school principals', teachers', and counselors' views on the importance of self-evaluation to the profession they practice, and the degree to which their school managements encourage, educators to carry out self-evaluation;

- How expertise in carrying out self-evaluation, educators' attitudes toward the necessity of continuous professional development, their interest in research work, and school managements' encouragement of teachers 
to carry out self-evaluation can function as the predictors of differences among respondents in attitudes regarding the importance of self-evaluation to the profession they practice.

\subsection{The Research Method}

The basic research methods were the descriptive and causal non-experimental methods of educational research. The research study was based on the quantitative research paradigm.

\subsection{The Sample}

A systematic sample of 1,530 respondents participated in the study. Primary and secondary schools located throughout all Slovenian regions were included. The sample, which has a good representativity, is further described in the text that follows.

The questionnaire about carrying out self-evaluation in primary schools was completed by 1,109 respondents from 107 schools. The schools' response rate was $71.3 \%$.

The questionnaire for primary-school teachers was completed by 913 teachers $(88.9 \%$ female and $11.1 \%$ male). The average age of the teachers was 42.39 years ( $\mathrm{SD}=9.20$ years); on average, they had 18.92 years of working experience $(\mathrm{SD}=10.75)$.

The questionnaire for primary-school counselors was completed by 92 counselors $(96.6 \%$ female and $3.4 \%$ male). The average age of the counselors was 46.15 years ( $\mathrm{SD}=9.53$ years); on average, they had 21.96 years of working experience $(\mathrm{SD}=10.33)$.

The questionnaire for primary-school principals was completed by 104 principals $(67.6 \%$ female and $32.4 \%$ male). The average age of the principals was 49.71 years $(\mathrm{SD}=6.73$ years); on average, they had 26.69 years of working experience $(\mathrm{SD}=7.45)$, and their mean length of service as principals was 8.95 years $(\mathrm{SD}=6.36)$.

The questionnaire that addressed self-evaluation in secondary schools was completed by 421 respondents from 33 secondary schools. The schools' response rate was $66.0 \%$.

The questionnaire for secondary-school teachers was completed by 360 teachers ( $72.4 \%$ female and $27.6 \%$ male). The average age of the teachers was 44.02 years $(\mathrm{SD}=8.27$ years); on average, they had 19.16 years of working experience $(\mathrm{SD}=8.83)$.

The questionnaire for secondary-school counselors was completed by 30 counselors, all of whom were female. The average age of the counselors was 41.77 years $(\mathrm{SD}=7.65$ years); on average, they had 15.93 years of working experience $(\mathrm{SD}=8.63)$.

The questionnaire for secondary-school principals was completed by 31 principals $(51.6 \%$ female and $48.4 \%$ male). The average age of the principals was 49.16 years ( $\mathrm{SD}=6.91$ years); on average they had 25.87 years of working experience $(\mathrm{SD}=7.58)$, and their mean length of service as principals was 9.19 years $(\mathrm{SD}=7.22)$.

\subsection{Sampling Procedures and the Instrument}

Our data were collected via the questionnaire that we prepared for principals, teachers, and school counselors working in primary and secondary schools. We designed six similar questionnaires that were adjusted to each group of respondents. The questionnaire was compiled according to the relevant literature from the field of self-evaluation practices. The validity of the questionnaire was tested with factor analysis (i.e., what percentage of variance is explained by the first factor) and its reliability with Cronbach's coefficient $\alpha$.

Table 1. Validity and reliability of the questionnaire

$\begin{aligned} & \% \text { of } \\ & \text { variance }\end{aligned}$

explained by the

first factor

\begin{tabular}{lll}
\hline A numeric scale rated the areas in which teachers and counselors carry & 44.721 & 0.872
\end{tabular} out self-evaluation.

$\begin{array}{ll}\text { The Likert scale assessed the attitudes of principals, teachers and } 27.270 & 0.829\end{array}$ counselors toward professional development, research, and self-evaluation. 
The data presented in table 1 demonstrate that the scales were sufficiently reliable (Cronbach's coefficient $\alpha \geq$ 0.60 ) and valid (the first factor always explained over $20 \%$ of the variance). The data collection, which was anonymous, was carried out in December 2012.

\subsection{Data Analysis}

Questionnaire data were processed at the levels of descriptive and inferential statistics. We used the frequency distribution ( $\mathrm{f}, \mathrm{f} \%$ ) of attributive variables, the basic descriptive statistics of numerical variables (arithmetic mean, dispersion), the chi-square test of hypothesis independence, Kullback's $2 \hat{I}$-test (where the condition for the chi-square test was not satisfied), Levene's test for equality of variances (the F-test), the t-test for independent samples or the approximate t-test, multiple regression to analyze the relations between an individual dependent variable and more independent variables, where the method of least squares was used, and all the selected variables were included in the model simultaneously (the Enter method). The data are shown in the tables. The percentages given for each individual answer were calculated with regard to the number of respondents to the question (i.e., valid answers) and not with regard to the number of all the participants in the research study.

\section{Results}

The educators in our study were asked about how frequently they carried out self-evaluation. To ensure the validity of responses, we started by defining self-evaluation as systematic data collection about a phenomenon with the intention of evaluating it and/or improving it on that basis. The responses revealed statistically significant differences $(2 \hat{I}=109.609, \mathrm{~g}=20, \alpha=0.000)$. Of those who replied that they frequently, or very frequently, carried out self-evaluation, the majority were primary-school teachers $(81.0 \%)$. The same response was offered by three quarters of the primary-school principals $(70.6 \%)$, two thirds of the secondary-school counselors $(66.7 \%)$, nearly two thirds of the secondary-school teachers $(64.4 \%)$, and a little more than one half of the primary-school counselors (55.1\%) and secondary-school principals $(51.6 \%)$. From the aspect of our examined topic, the results are very encouraging, since in all the groups more than one half of the respondents replied that they frequently, or very frequently, carried out self-evaluation.

We were subsequently interested in how frequently primary- and secondary-school teachers carried out self-evaluation in specific areas of their pedagogical work. The teachers assessed the frequency of their self-evaluations on a five-level assessment scale, with 1 meaning they never carried out self-evaluation and 5 meaning that they performed self-evaluations very frequently.

Table 2. The frequency of primary- and secondary-school teachers' implementation of self-evaluation in specific areas of their pedagogical work

\begin{tabular}{|c|c|c|c|c|}
\hline How frequently teachers evaluate & $\begin{array}{l}\bar{x} \\
\text { (primary-school } \\
\text { teachers) }\end{array}$ & $\begin{array}{l}\bar{x} \\
\text { (secondary-school } \\
\text { teachers) }\end{array}$ & $t$-test & $\alpha$ \\
\hline achieving the goals of the lesson & 4.39 & 3.99 & 8.851 & $0.000 *$ \\
\hline students' achieved knowledge & 4.44 & 4.11 & 7.941 & $0.000 *$ \\
\hline $\begin{array}{l}\text { students fulfilling their duties (e.g., } \\
\text { doing homework) }\end{array}$ & 4.50 & 3.86 & 11.109 & $0.000 *$ \\
\hline correctness of students' homework & 4.29 & 3.72 & 9.084 & $0.000 *$ \\
\hline $\begin{array}{l}\text { social relationships in the classroom } \\
\text { (the group's integration and the } \\
\text { position of individual students) }\end{array}$ & 3.85 & 3.40 & 8.099 & $0.000 *$ \\
\hline students' attitudes toward knowledge & 3.75 & 3.60 & 2.854 & $0.004 *$ \\
\hline students' work habits & 3.89 & 3.62 & 5.007 & $0.000 *$ \\
\hline $\begin{array}{l}\text { students' knowledge of learning } \\
\text { strategies }\end{array}$ & 3.50 & 3.17 & 6.147 & 0.000 \\
\hline teachers' cooperation with parents & 3.76 & 3.37 & 6.021 & $0.000 *$ \\
\hline students' cooperation during classes & 4.33 & 4.12 & 4.636 & 0.000 \\
\hline students' respect for rules & 4.34 & 4.06 & 5.846 & 0.000 \\
\hline
\end{tabular}

Note. The approximate $t$-test was calculated. 
In accordance with the assumption about the equality of variances, the $t$-test for independent samples or the approximate $t$-test (where the condition of variance equality was not fulfilled) showed statistically significant differences between primary- and secondary-school teachers regarding their assessments of the frequency of self-evaluation in all areas of their work. The mean values of the frequency of carrying out self-evaluation, as reported by primary-school teachers, are higher in all areas than those given by secondary-school teachers.

The data demonstrate that primary-school teachers carry out self-evaluation most frequently in the following areas: students fulfilling their duties (e.g., doing homework) $(\overline{\mathrm{x}}=4.50)$; students' achieved knowledge $(\overline{\mathrm{x}}=4.44)$; achieving the goals of the lesson $(\overline{\mathrm{x}}=4.39)$; students' respect for rules $(\overline{\mathrm{x}}=4.34)$; students' cooperation during classes $(\overline{\mathrm{x}}=4.33)$; and the correctness of students' homework $(\overline{\mathrm{x}}=4.29)$. On the other hand, secondary-school teachers carry out self-evaluation most frequently in the following areas: students' cooperation during classes ( $\overline{\mathrm{x}}$ $=4.12)$; students' achieved knowledge $(\overline{\mathrm{x}}=4.11)$; students' respect for rules $(\overline{\mathrm{x}}=4.06)$; achieving the goals of the lesson $(\overline{\mathrm{x}}=3.99)$; and students fulfilling their duties $(\overline{\mathrm{x}}=3.86)$.

Self-evaluation is a comprehensive process of planned and systematic data collection in various areas of the educational institution's work. It also analyzes and interprets information so as to give an insight into the existing situation in the organization or to obtain feedback about its working quality and efficiency. Using self-evaluation, we can examine the strengths and weaknesses of educational institutions to determine how they are functioning. The essential aim of self-evaluation is to ensure quality, development, and progress in educational institutions. Consequently, the conclusions derived on the basis of self-evaluation must lead to the preparation of the action plan, which includes the introduction of changes, improvements, and innovation to the appropriate areas. Such conclusions may also confirm that our work in areas that demonstrate positive self-evaluation results is good and should be continued. Self-evaluation can be carried out by a school or by an individual educator. The latter provides regular information for educators about the quality of their work: regular assessment of the areas that are usually related to the subject(s) and class(es) that the teacher teaches. This is a systematic form of reflection or planned, systematic data collection, analysis, and interpretation with the intention of assessing and improving the quality of one's pedagogical work. Individuals can collaborate with their colleagues or school management, who can provide them with personal and professional support. Self-evaluation at the school level is more comprehensive and usually incorporates more areas of quality assessment simultaneously, as well as more different interest groups (school management, other educators, students, their parents, and representatives of other professional institutions). To carry out a quality self-evaluation, it is important for a quality working group to be formed in the educational institution to manage the whole project and to make the most important decisions At the start of the self-evaluation process, key decisions about the priorities and content areas of quality assessment are made. Afterwards, the quality group prepares the content, a methodological plan for the self-evaluation research study, and instruments for data collection (either selecting already prepared self-evaluation instruments or developing specific instruments for its specific needs). The basic tasks of the quality group also include data collection, analysis and interpretation, and the preparation of the report on research outcomes, as well as planning and organizing discussions in the educational institution. Representatives of all participating groups are part of the discussions, in which self-evaluation research outcomes are presented and suggestions for further plans are approved.

Self-evaluation can become an important factor of growth and development, but, according to Medveš (2000, p. 17), an adequate school atmosphere must be created for self-evaluation in schools and other educational institutions to be carried out. The essence of an atmosphere that can assure quality lies in the school's efforts to improve its work as a permanent expert activity (ibid.). In our research study, we were also interested in how the responding educators assess the importance of self-evaluation to the profession they practice. Some studies (e.g., Van Petegem, Verhoeven, Buvens, \& Vanhoof, 2005) suggest that principals are generally more aware of the importance of self-evaluation than teachers. Overall, teachers are not entirely convinced of the importance of self-evaluation, whereas principals are. Principals show a more positive attitude toward self-evaluation and are more convinced of its usefulness (ibid.). Although there were statistically significant differences among the respondents in our study $(2 \hat{I}=71.935, \mathrm{~g}=20, \alpha=0.000)$, the majority of them said that they found self-evaluation important, or very important, to the profession they practice. The largest share of the respondents who expressed that opinion comprised primary-school principals $(89.7 \%)$ and secondary-school principals (86.2\%), followed by primary-school counselors $(80.5 \%)$ and primary-school teachers $(79.5 \%)$. The percentages of secondary-school counselors (66.7\%) and secondary-school teachers $(66.4 \%)$ who shared that opinion are somewhat smaller.

Subsequently, we studied how expertise in the implementation of self-evaluation, respondents' attitudes toward the necessity of continuous professional development, and their interest in research work, as well as school 
managements' encouragement of teachers to carry out self-evaluation, can function as the predictors of opinion differences among respondents in attitudes regarding the importance of self-evaluation to the profession they practice. We assessed the model with multiple regression, in which the method of least squares was used and all the selected variables were included in the model simultaneously (the Enter method).

Table 3. Arithmetic means and standard deviations for the following variables: Attitudes toward the importance of carrying out self-evaluation, school managements' encouragement of teachers to carry out self-evaluation, educators' interest in research work, their attitudes toward the necessity of continuous professional development, and the expertise in carrying out self-evaluation

\begin{tabular}{lll}
\hline & $\overline{\mathrm{x}}$ & $\mathrm{S}$ \\
\hline $\begin{array}{l}\text { Attitudes toward the importance of carrying out } \\
\text { self-evaluation }\end{array}$ & 3.98 & 0.75 \\
$\begin{array}{l}\text { School managements' encouragement of teachers to carry out } \\
\text { self-evaluation }\end{array}$ & 3.81 & 0.83 \\
$\begin{array}{l}\text { Educators' interest in research work } \\
\begin{array}{l}\text { Attitudes toward the necessity of continuous professional } \\
\text { development }\end{array}\end{array}$ & 3.79 & 0.85 \\
\begin{tabular}{l} 
Expertise in carrying out self-evaluation \\
\hline
\end{tabular} & 2.92 & 0.93 \\
\hline
\end{tabular}

Table 4. Coefficients of determination

\begin{tabular}{lllll}
\hline Model & $\mathrm{R}$ & $\mathrm{R}^{2}$ & ${\text { Adjusted } \mathrm{R}^{2}}$ & $\begin{array}{l}\text { Standard } \\
\text { error of the } \\
\text { estimate }\end{array}$ \\
\hline $\begin{array}{l}\text { The impact of predictors on attitudes } \\
\text { toward the importance of carrying out } \\
\text { self-evaluation }\end{array}$ & & 0.46 & 0.211 & 0.209 \\
\hline
\end{tabular}

The coefficient of determination $\left(\mathrm{R}^{2}\right)$ shows that the obtained regression model explains $21.1 \%$ of the variance. The value of ANOVA is statistically significant $(\mathrm{F}=93.056 ; \alpha=0.000)$, meaning that the presented model statistically significantly improves the forecast of the impact of educators' attitudes toward the importance of carrying out self-evaluation.

Table 5. Coefficients of regression and $t$-statistics

\begin{tabular}{|c|c|c|c|c|}
\hline $\begin{array}{l}\text { The impact of predictors on attitudes toward the } \\
\text { importance of carrying out self-evaluation }\end{array}$ & $\begin{array}{l}\text { Unstandardized } \\
\text { coefficient of } \\
\text { regression (B) }\end{array}$ & $\begin{array}{l}\text { Standardized } \\
\text { coefficient of } \\
\text { regression (B) }\end{array}$ & $t$ & $\alpha$ \\
\hline $\begin{array}{l}\text { School managements' encouragement of } \\
\text { educators to carry out self-evaluation }\end{array}$ & 0.074 & 0.082 & 3.345 & 0.001 \\
\hline Educators' interest in research work & 0.215 & 0.246 & 9.915 & 0.000 \\
\hline $\begin{array}{l}\text { Attitudes toward the necessity of educators' } \\
\text { continuous professional development }\end{array}$ & 0.382 & 0.222 & 9.149 & 0.000 \\
\hline Expertise in carrying out self-evaluation & 0.148 & 0.185 & 7.381 & 0.000 \\
\hline
\end{tabular}

It is evident from the model (table 5) that all the factors have an important influence on the respondents' attitudes toward self-evaluation. On the basis of the standardized coefficients of regression, it can be concluded that the respondents' attitudes toward the importance of carrying out self-evaluation are mostly influenced by the variables "educators' interest in research work" and "attitudes toward the necessity of educators' continuous 
professional development." Those educators whose knowledge of conducting self-evaluation is greater also attach more importance to carrying out self-evaluation. School management's encouragement has a further, statistically significant impact on teachers' views on the importance of conducting self-evaluation.

\section{Discussion}

If self-evaluation is to provide us with accurate data that can serve as a basis for further educational plans, it is vital for self-evaluation research studies to be in accordance with methodological standards. Therefore, it is very important that study programs for future educators approach self-evaluation by combining methodological and content knowledge. Study content regarding the methodological planning and carrying out of self-evaluation should be integrated into the courses dealing with the study of methodology. Study contents on assessing and assuring quality in education should also be part of other courses, at least those in which students gain fundamental pedagogical knowledge, in the study programs educating future educators. The awareness of the importance of carrying out self-evaluation to assessing and assuring the quality of one's work, as well as to one's own professional development, can primarily be developed by students (future educators) if they gain knowledge about it during a variety of courses. Here, interdisciplinary seminars can prove to be a great advantage by helping students to give meaning to methodological knowledge and to relate research work to other professional activities. Vogrinc, Valenčič Zuljan and Krek (2009) maintain that it is necessary for students to acquire sound research knowledge (at least basic methodological knowledge and statistical procedures used in pedagogy) and to gain their first concrete experiences in research work during undergraduate studies. We can expect that the teachers who gain positive experiences and basic competences related to research during their studies will extend and improve their knowledge during the process of continuing in-service training.

Educators need research based knowledge but they also have a right and obligation to assess and reflect on what works. They need evidence. This means assessing why it is worthwhile to apply something in their work. Evidence here comes from different sources. Evidence can be based on research reports and studies or thematic reviews of research. An urgent issue concerns the quality of the evidence and which kinds of evidence we can trust (Marston \& Watts, 2003; Thomas, 2004; Agalianos, 2006; Niemi, 2008; Hočevar, Kovač Šebart, \& Štefanc, 2013). Educators must have basic knowledge of research methods and some competence to evaluate the relevance and quality of research results. They need scientific literacy. Without this skill they are merely actors who are applying orders coming from outside their practice. They need scientific literacy in order to understand on which grounds they can build their work. Without this understanding they have very few opportunities to learn new and question earlier knowledge and practices (Niemi, 2008, p. 187).

A school's successful self-evaluation depends on mutual support, trust, openness, and cooperation among educators (Hargreaves \& Fullan, 1992; Vanhoof, Van Petegem, Verhoeven, \& Buvens, 2009). The pedagogical head of a school has an exceptionally important role in developing an adequate atmosphere for assuring quality. Consequently, we asked our respondents about the degree to which their school management encourages educators to carry out self-evaluation. It is interesting that the share of educators working in primary schools (approximately three quarters of school counselors, teachers, and principals) who think that their school's management encourages, or greatly encourages, self-evaluation is bigger than the share of educators working in secondary schools (nearly three fifths of principals and a good half of school counselors and teachers) who hold that same opinion. Their responses reveal statistically significant differences $(2 \hat{I}=126.098, \mathrm{~g}=20, \alpha=0.000)$. Each educational institution should develop a cooperative atmosphere and reach a consensus on common expectations and values based on the vision and mission of the institution, with which each member of the group can identify. It is crucial for each educator to be aware of his/her responsibility or role in the process of comprehensive quality assurance. Educational institutions should also foster the belief that carrying out self-evaluation is a fundamental factor in assuring the quality of educational work. Motivation for lifelong learning, readiness, and qualification for constant critical self-evaluation, acquisition of new knowledge, and the introduction of new findings to pedagogical practice are important factors in the professional development of each educator. The concept of lifelong learning is closely related to professional development (Vidmar, 2014), the latter being dependent on a number of personal (e.g., personal interests and expertise in different areas), institutional (e.g., school's characteristics and identity, students' characteristics and abilities, and school's atmosphere and culture), as well as national (e.g., the system of continuing in-service training) factors. We believe it is particularly relevant to stress the importance of relating the individual's professional development to the development and quality of the school as a whole. According to Mac Beath (2011, p. 361) this implies a paradigm shift from the passive and subordinate role to the active role in which educators, as the first agents of self-evaluation, assume the responsibility for their individual and collective professional development. 


\section{References}

Agalianos, A. (2006). Crossing borders: The European Dimension in Educational and Social Science Research. In J. Ozga, T. Seddon, \& T. Popkewitz (Eds.), Education Research and Policy (pp. 43-76). London: Routledge.

Dahlgaard, J. J., Kristensen, K., \& Kanji, G. K. (2002). Fundamentals of Total Quality Management. Cheltenham: Nelson Thornes Ltd.

Gaber, S., \& Kos Kecojevič, Ž. (2011). Zagotavljanje kakovosti kot del dispozitiva varnosti [Quality Assurance as a Part of Dispositive of Security]. In Ž. Kos Kecojevič, \& S. Gaber (Eds.), Kakovost v šolstvu v Sloveniji [Quality of Education in Slovenia] (pp. 10-36). Ljubljana: Pedagoška fakulteta.

Hargreaves, A., \& Fullan, M. (1992). Understanding Teacher Development. New York: Teachers College Press.

Hočevar, A., Kovač Šebart, M., \& Štefanc, D. (2013). Curriculum Planning and the Concept of Participation in the Reggio Emilia Pedagogical Approach. European Early Childhood Education Research Journal, 21(4), 476-488. http://dx.doi.org/10.1080/1350293X.2013.845437

MacBeath, J. (2011). Vodenje učenja v samoevalvacijski šoli [Leadership of Learning in Self-evaluating School]. In Ž. Kos Kecojevič, \& S. Gaber (Eds.), Kakovost v šolstvu v Sloveniji [Quality of Education in Slovenia] (pp. 347-366). Ljubljana: Pedagoškafakulteta.

Marston, G., \& Watts, R. (2003). Tampering with the Evidence; A Critical Appraisal of Evidence-Based Policy-Making. The drawing board: An Australian review of public affairs, 3(3), 143-163.

Medveš, Z. (2000). Kakovost v šoli [Quality in School]. Sodobna pedagogika [Journal of Contemporary Educational Studies], 51(4), 8-26.

Niemi, H. (2008). Advancing Research into and during Teacher Education. In B. Hudson, \& P. Zgaga (Eds.), Teacher Education Policy in Europe: A voice of Higher Education Institutions (pp. 183-208). Umeå: University of Umeå, Faculty of Teacher Education.

Powell, T. (1995). Total quality management as competitive advantage: A review and empirical study. Strategic Management Journal, 16(1), 15-37. http://dx.doi.org/10.1002/smj.4250160105

Rossi, H. P., \& Freeman, E. H. (1993). Evaluation, a sistematic approach. Newbury Park: Sage Publications.

Sallis, E. (2002). Total Quality Management in Education. London, New York: Routledge.

Stenhouse, L. (1975). An Introduction to Curriculum Research and Development. London: Heinemann.

Stufflebeam, D. L., \& Shinkfield, A. J. (2007). Evaluation Theory, Models and Applications. San Francisco: Jossey-Bass/ Pfeiffer.

Stronach, I. (1999). Shouting theatre in a crowded fire: "Educational effectiveness" as a cultural performance (Evaluation). London: Sage Publications.

Thomas, G. (2004). What is evidence? Introduction. In G. Thomas, \& R. Pring (Eds.), Evidence Based Practice in Education. Maidenhead: OUP/ McGraw-Hill.

Vanhoof, J., Van Petegem, P., Verhoeven, J. C., \& Buvens, I. (2009). Linking the Policymaking Capacities of Schools and the Quality of School Self-evaluations. The View of School Leaders. Educational Management Administration \& Leadership, 37, 667-686. http://dx.doi.org/10.1177/1741143209339653

Van Petegem, P., Verhoeven, J. C., Buvens, I., \& Vanhoof, J. (2005). Zelfevaluatieen Beleidseffectiviteit in Vlaamse Scholen. Het Gelijke Onderwijskansenbeleidals Casus [Self Evaluation and Policy Effectiveness of Schools: A Case Study of the Flemish Equal Chances Policy]. Gent: Academia Press.

Vidmar, T. (2014). New Dimensions of Understanding of Life long Learning from Antiquity to Comenius. Review of European Studies, 6(3), 91-101.

Vogrinc, J., \& Valenčič Zuljan, M. (2009). Action research in schools-An important factor in teachers' professional development. Educational studies, 35(1), 53-63.

\section{Notes}

Note 1. The notion of approach is understood here as a set of policies, procedures, rules, criteria, tools, mechanisms and instruments of monitoring or verification. 


\section{Copyrights}

Copyright for this article is retained by the author(s), with first publication rights granted to the journal.

This is an open-access article distributed under the terms and conditions of the Creative Commons Attribution license (http://creativecommons.org/licenses/by/3.0/). 